Chapman University

Chapman University Digital Commons

Marriage and Family Therapy Faculty Articles and Research

$1-13-2022$

Posttraumatic Growth in Women With a Long-Standing Experience of Involuntary Childlessness in the Czech Republic

Gabriela Ďurašková

Brennan Peterson

Follow this and additional works at: https://digitalcommons.chapman.edu/mft_articles

Part of the Counseling Commons, Marriage and Family Therapy and Counseling Commons, Other Mental and Social Health Commons, Other Psychiatry and Psychology Commons, and the Other Psychology Commons 


\section{Posttraumatic Growth in Women With a Long-Standing Experience of Involuntary Childlessness in the Czech Republic}

\section{Comments}

This is a pre-copy-editing, author-produced PDF of an article accepted for publication in Journal of Humanistic Psychology in 2022 following peer review. The definitive publisher-authenticated version is available online at https://doi.org/10.1177/00221678211068291.

\section{Copyright}

The authors 


\title{
Posttraumatic growth in women with a long-standing experience of involuntary childlessness
}

\section{in the Czech Republic}

Gabriela Ďurašková, Department of Clinical Psychology, Motol University Hospital, Prague, CZ Brennan Peterson, Department of Psychology, Chapman University, Orange, CA, USA.

Correspondence concerning this article should be addressed to Gabriela Ďurašková, Department of Clinical Psychology, Motol University Hospital, V Uvalu 84, Prague, 150 06, Czech Republic (email: gabriela.duraskova@gmail.com).

\begin{abstract}
This qualitative research study aimed to examine aspects of posttraumatic growth (PTG) in women with a long-standing experience of involuntary childlessness. In-depth semi-structured interviews, lasting an average of 53 minutes, were conducted in the Czech Republic. Twenty-four women, averaging 38.8 years old with an average of 6.2 years of infertility experience, participated. They were asked how involuntary childlessness affected/changed their partnerships, sexual life, job, future plans, attitude to children/values/faith, and leisure time. Participants shared both positive and negative aspects of the infertility experience. Data were analyzed using thematic analysis. Five main themes of PTG were identified: strengthening of partnership, greater humility, deeper selfappreciation, reassessment of relationships, and changes in philosophy of life. These findings could be useful to mental health providers to facilitate the PTG process in patients.
\end{abstract}

\section{Key words}

Posttraumatic growth, infertility, childlessness, treatment failure 


\section{Posttraumatic growth in women with a long-standing experience of involuntary childlessness in the Czech Republic}

\section{Introduction}

Couples who yearn for a baby yet have difficulty conceiving face an emotionally, physically, and socially challenging experience long rooted in history. From Biblical accounts to Greek and Egyptian histories, the experience of infertility has been characterized by significant loss, sorrow, grief, and suffering. Today, as many as $15 \%$ of Czech couples have fertility problems, and 72.4 million females report fertility problems worldwide (Boivin et al., 2007; Slepičková, 2014). It is estimated that only $56 \%$ of couples worldwide with an infertility diagnosis seek medical treatment (Boivin et al., 2007), primarily from their gynecologists or through fertility specialists using Assisted Reproductive Technologies (ART), including in vitro fertilization (IVF).

Qualitative research reports show that an unexpected medical diagnosis of infertility is related to increased psychological distress, including threats to one’s identity (Konečná, 2009; Alamin et al., 2020). For example, infertility often leads women to perceive themselves as incompetent or insufficient (Slepičková, 2006, Clarke, Martin-Matthews \& Matthews, 2006) and men may feel emasculated (Hanna \& Gough, 2015), often resulting in low self-confidence (Daniluk \& Tench, 2007).

Even if only one partner is diagnosed with infertility, the relational stressor impacts both members of the couple (Peterson et al., 2009). Childless couples have to solve many dilemmas in their relationship, which can make their everyday life more difficult. Changes in their sexual life, as instructed by a specialist, may cause increased sexual stress (Luk \& Loke, 2015; Batool \& de Visser, 2016) and a loss of spontaneity (Ratislavová \& Kašová, 2009). Long-standing unsuccessful efforts to conceive are also frequently connected with an overall change of lifestyle. Childless couples are often excluded (or exclude themselves) from social situations, lose friends who were 
able to have children, and feel stigmatized (Sternke \& Abrahamson, 2015). In addition, women may be reluctant to engage in longer-term work projects or change jobs (Slepičková, 2009).

Because infertility is a heavy burden that radically affects everyday life, the majority of research examining infertility and psychological adjustment emphasizes the negative factors connected to this difficult situation. Fewer studies examine a strength-based approach regarding the potential positives of this challenging life stressor. This study considers whether there are positive outcomes as a result of infertility struggles - i.e., posttraumatic growth (PTG).

Tedeschi and Calhoun (2004) broadly define PTG as "positive psychological change experienced as a result of the struggle with highly challenging life circumstances" (p. 1). In other words, it is the positive personality change developed after experiencing a traumatic situation (Calhoun \& Tedeschi, 2006; Slezáčková, 2009). PTG is both a process and an outcome, typically manifested as positive changes in one's attitude towards oneself, relationships, and life philosophy (Calhoun \& Tedeschi, 1999).

While some qualitative studies have identified PTG as an emerging theme for women struggling with infertility (Berger, Paul \& Henshaw, 2013, Lee et al., 2009, Daniluk, 2001), PTG was not the main focus of these studies. Rather, the majority of studies centered around PTG use quantitative research methods (Paul et al., 2010; Yu et al., 2014, Kong et al., 2018). These studies found comparable levels of PTG among people who experienced infertility and those who experienced high-stress/traumatic events (colorectal cancer survivors, survivors of severe car accidents, Bosnian refugees, etc.). However, to the best of our knowledge, no published qualitative studies have directly examined the presence of PTG or how it is experienced in women with infertility, which may offer deeper insight into this phenomenon. 
The purpose of this study was to discover what aspects of PTG can be found in Czech women who have had long-term experience with involuntary childlessness. The use of qualitative methods allowed us to explore this subject in-depth and give voice to the experiences of women who saw positive changes and growth as a result of their infertility.

\section{Method}

\section{Participants}

A total of 24 women participated in this study. Participants were between the ages of 30 and 53 years (average age was 38.8 years; SD 5.4) and had been trying to conceive for an average of 6.2 years (SD 2.6; ranging from 2.5 years to 10 years). Seventeen of the women (71\%) tried to conceive for five years or more. Thirteen had unsuccessful experiences with IVF treatment, 11 had repeatedly unsuccessful infertility treatment by methods other than IVF. Over $90 \%$ of participants (22/24) had a university education, while two participants had secondary education. At the time of the interview, 11 women (46\%) were childless, 8 (33\%) had a biological child, and 5 (21\%) had an adopted child (see Table 1).

To be included in the study, participants must have had a considerably traumatic, longstanding experience with infertility defined as: 1) experiencing more than one failed fertility treatment; 2) having no children prior to receiving treatment; 3) having undergone the last unsuccessful treatment more than 6 months prior to the interview. The women were invited to join the study using purposive sampling techniques - via snowball (Miovský, 2006). Eligible participants were contacted by e-mail, were provided information about the research (its purpose, brief description of interview topics), and were assured their participation in the study would be anonymous and strictly voluntary. Of the twenty-eight women who were contacted, two did not 
participate because of anticipated distress in discussing their experience, and two declined to participate without a stated reason. Therefore, 24 women agreed to participate in the study.

The study was approved as a doctoral project by a university faculty review committee that protects human subjects and provides ethical procedures for data collection and analysis. Because of the sensitive nature of the interviews, transparency was used to inform participants about the contents of the interview to allow them to prepare and be better informed about the purpose of the research.

\section{Materials and Procedure}

To measure the experience of involuntary childlessness, in-depth semi-structured interviews were conducted by the first author in the Czech Republic. Interviews were recorded, and transcribed. The average length of each interview was 53 minutes (range 26-102 minutes). Participants were asked how involuntary childlessness affected or changed their life. Interviews focused solely on the time participants intentionally tried to conceive before having any children, if at all. While our aim was to study the possible positive aspects of their experience with infertility, interviews captured the complete experience in order to avoid invalidating the challenges participants have faced (Calhoun \& Tedeschi, 2006; Slezáčková, 2009).

All communication with the participants was conducted by the first author - a psychologist and psychotherapist who treats individuals, couples, and families. She has long-term personal experience with involuntary childlessness, which has been resolved through ART; this fact was also subject to extensive reflective work. She was aware of her assumptions and therefore used regular supervision, audit trail (Lincoln \& Guba, 1985), and field notes, which were also used as a reflective diary. She worked extensively with it in the interest of trustworthiness. 
After participants had given informed consent, the times and locations of the interview were established. The women who participated in the study were able to choose the interview location so they would feel more comfortable speaking freely about their experience. Fourteen women (54\%) chose a private room in a Czech coffee shop, and ten women $(42 \%)$ chose to be interviewed in their homes. While participants were allowed to refuse to discuss any topic, none chose to do so. During the interviews, the interviewer's relationship with the participants was mainly discussion-based and cooperative, producing authentic data. Open-ended questions and empathic responses were used throughout the interviews, which resulted in a thorough, meaningful description of the individual's experience. Many participants felt that sharing their experience was meaningful and could help other women in similar situations if the outcomes were published. Participants talked about their experience frankly, and some expressed relief and gratitude for the opportunity to talk about the challenges they experienced in such an in-depth way. During the interviews, when the participants showed their emotional pain, supportive questions and comments were offered in order to help them recover. None of the women chose to end the interview prematurely or left the interview distressed.

Participants were initially asked, "how has infertility affected (changed) your life?". This question then led to the nine subtopics (spheres of life) based on the Life Satisfaction Questionnaire (Fahrenberg et al., 2001). In the framework of specific subtopics, participants were asked whether infertility brought them anything positive or negative in that context. We encouraged participants to give detailed narration about the changes they perceived in their emotions, thoughts, or behaviors in each of these nine areas: (1) partnership; 2) sexual life; 3) relationships with friends, acquaintances, and relatives; 4) job and career; 5) future plans; 6) attitude towards children; 7) 
values and faith; 8) attitude towards oneself and one's health; 9) leisure time, interests, and hobbies.

Participants were also asked an open-ended question at the conclusion of the interview to provide an opportunity to include anything they had not been asked. Participants were also given an opportunity to contact the researcher following the interview if needed. Two women sent a follow-up e-mail after the interview to make additional comments to certain topics that were discussed during the interview.

\section{Data analysis}

Data from the interviews were transcribed and analyzed by thematic analysis (Nowell, Norris, White, \& Moules, 2017) using the six steps noted in Braun \& Clarke, 2012. One person coded the transcribed interviews, then consulted with a supervisor, and any conflicting results were resolved consensually. Themes were created by grouping together similar codes. Smaller themes (subcategories) were grouped into more general themes (categories). The aim was to find important themes relevant to our research question. The names of the participants were abbreviated in the text for anonymity preservation.

\section{Results}

Using thematic analysis, we found five basic themes of PTG: strengthening of partnership, humility, self-appreciation, reassessment of social relationships, and philosophy of life. Table 2 presents the frequency of participants who reported PTG across each of the 5 themes. Participants endorsed the five PTG themes regardless of whether they had a child during the study.

\section{Strengthening of partnership}

"It got me closer to my husband. We both wanted it, we both tried." (M34042) 
All of the women commented that infertility affected their partner relationships. Twentytwo of the 24 participants stayed together following the infertility journey. All the participants mentioned that infertility brought some positive elements to their partnership or influenced their attitudes towards their partner. These statements were divided into three sub-themes: 1) distinguishing good qualities of a partner; 2) improving partner communication; 3) strengthening the partnership bond.

Some women told us they appreciated their partner's support and their efforts to keep their relationship together. They realized it must have been difficult for their partner to continue to be supportive in a situation when they (women) were overwhelmed by their own suffering. Some participants - 11 women $(\mathrm{w})$ - were surprised that their partners shared their values and goals related to treatment.

“It was very good to know he supports me. That he... was incredibly patient.” (D4608A)

Because of the infertility treatments, partners had to discuss subjects about which they had previously never spoken. The experience pushed them to have more open communication with their partner about topics such as sex $(2 \mathrm{w})$, readiness to accept/not accept a child who is not biologically theirs $(7 \mathrm{w})$, and more in-depth communication about their emotions $(3 \mathrm{w})$.

"The partnership gets better thanks to various topics and necessity to talk about some things... not only the relationship as such but also its intimate aspect, we simply learn new things, talk about them, try to verbalise our emotions." (S36050)

Two women said their infertility made them see the dysfunctions of their partnerships more clearly and formulate their needs more precisely. This clarity resulted in them permanently ending their partnerships. However, the vast majority of women $(22 / 24)$ shared that their relationship became more stable due to the experience of infertility. They spoke about "shared suffering" 
(V38100), "pain" (F30070), and efforts to reach shared goals. It was very important for most women that they and their partners wanted to stay together in the future - in life without a child, with an adopted child, or undergoing treatment through assisted reproduction. They also stated how important it was for them to agree with their partner on how much to share with others (family, friends, etc.) about their experience and emotions.

The women also spoke about "unifying"” (P41052) with their partner and strengthening their partnership's overall bond. Some women stated that their partnership became stronger after deep crises, such as temporary separation (3w).

"I think our relationship is more harmonic and stronger now. I was worried for a long time that he would leave me because I can't have a baby with him. This was the reason I wanted our separation, I told him "leave me now, not when I am forty or more, I just can't have your children." It was very hard for us. Now I'm not worried anymore. I just feel that I did as much as possible and we love each other and that's it." (T35070)

\section{Humility}

"I think, that I'm really more..., more like humble." (T35070)

Acquiring deeper personal humility through the experience of infertility was mentioned in 21 interviews; only three women did not discuss humility. Humility was defined as acquiring new, realistic views of life, admitting one's limits, and evaluating one's potential. The women referenced the word "humility" either explicitly (6w) or implicitly through the content of their statements (15w). These statements were divided into three subthemes: 1) awareness that we cannot control everything in our lives; 2) understanding that we cannot plan our future to the detail; 3) considering a child as a gift.

Infertility seemed to challenge the universal assumption that it would be easy to conceive. Most women stated that infertility was the first life experience where they could not reach their 
planned goal. This was especially difficult for the women who had been successful in their lives before: finishing their studies at the chosen university, finding a partner suitable for being a father of their child, succeeding in a chosen career. Because of this, the women suffered a shock when they could not reach another goal, something they assumed would happen without effort.

"It caused something like a deep humbleness inside me. I have always been the one who plans everything: I'm going to finish my studies, this will be followed by a good job, marriage and a baby. I got a tough lesson, I think." (E322,5T)

In the context of understanding that everything in life cannot be completely planned, eight women stated they realized that life is quite different from what one thinks and that they could not organize and control it even through a great effort.

"Certainly, you put up with the fact that you can't control some things in your life. This makes you more humble ... And I hope that I will never come to believe, that your life is completely the result of your effort. That you are able to make it totally contended, in accordance with your ideas and dreams." (K39040)

Ten women felt a certain relief when they realized that not all of the events in their life were purely the result of their effort. They understood that plans are not always important because life is unpredictable and can bring many unexpected situations. Some of them mentioned they learned to live in the "here and now" (P41052, J352,52), instead of anxiously making some ideas about their life in the future.

“... (it was) an important experience... to learn that one can't know what may happen in life. Maybe I once was more willing, prone to planning and now, when I have a problem, I can imagine so many consequences ... It's no use to rack one's brain before something comes. I learned to take things as they come..."(D3903A)

The category 'humility' also includes realizing that having a baby is not a guarantee or their choice but rather is a gift. It means recognizing that having a baby is not a commonplace or the 
result of one's effort. Seven women spoke about an acquired and deepened respect for the gift of life as such, that "every new life is a miracle, in fact." (F30070).

"I realized that children are not only an item in my plans. They come into our lives as a gift." (G33050).

\section{Self-appreciation}

"I came to know myself through this experience, so it was quite useful for me." (L41081)

In all 24 interviews, women explained that their experience with infertility led them to some new knowledge about themselves. They had to "stop" and look in the "mirror." (I44032, L41081). The majority of these personal discoveries demonstrated PTG and were sorted into three thematic sub-themes: 1) self-worth as a childless woman; 2) pride that one can endure more than she expected; 3) thinking of one's body - a different (healthy) lifestyle.

Only two of the respondents stated that motherhood had not always been their priority, but after some time, they had gotten used to the idea that they would become mothers. However, most of the participants stated that they saw being a mother as a natural part of their lives. They felt it was their "mission" (M38031) or "most important life assignment" (J47102) here on earth. They lived being more or less aware that motherhood is the fulfillment or completion of life.

All the women further described that not only themselves but also their partner, relatives, friends, etc., expected, without doubt, that they would have children. When this vision began to fall apart, and they could not become mothers for a long time, they felt "insufficient" (J47102), “incompetent" (S36050), and "defective." (J41100, T35070). They questioned their self-worth as women without children and struggled with feelings of insufficiency and inferiority. After a lengthy struggle with these beliefs, ten participants concluded that a woman has worth even without motherhood. 
"(I finally realized) that life doesn't end with the fact that I cannot have a baby... That's it. Not being a biological mother doesn't mean that I'm worthless. '(S36050)

"A child simply is not the core of marriage. This was a very important sentence for me, because I told myself that I had to look for a partner that would accept me as a childless and infertile woman - and if he would not, he was not good enough for me... that a woman's worth is not lessened by the fact she is not able to have a child." (K53100)

The participants spoke mainly about feelings of hopelessness, senselessness, and deep psychic suffering related to their experience of infertility. During the interviews, many women were surprised by their ability to cope, despite their long experience of unfulfilled desire, useless effort, and persistent seeking of other areas of fulfillment. They appreciated that they did not fall apart and, on the other hand, emphasized what they endured (14 women explicitly). The women felt a certain pride, that without regard to how hurtful the topic had been or was for them, they proved themselves to be stronger than they expected initially.

"so I realized that I'm strong and I'm going to survive. Strong ... I don't know, sometimes I felt so lost... I didn't know if I would be able to endure it and live in a family where everyone else had children ... I don't know, I think I'm proud of myself." (F30070)

"I think I could have taken it much worse. I am up and running. I am not broken. It could have been worse. I could have fallen apart, but I haven't, so far." (K39040)

All the women interviewed stated that their experience affected their relationship with their bodies. Sometimes they felt angry that their body betrayed them, and they began to pay more attention to it. They adopted a healthier lifestyle during their years of infertility and tried to change many things, including their diet, physical activity, sleep, and taking better care of themselves generally. Many of them started to be interested in alternative medicine, yoga, etc. 
"It's just... it changes all your priorities, everything - including your lifestyle, because you start thinking more thoroughly while trying to conceive. What you eat and drink, your care for your body - it also affected my health."(M34042)

"Well, I started to care for my health better-I exercised more, relaxed actively and tried to have a quite healthy regime. I certainly began to be more interested in it and thought about it more." (J41100)

Some women's ( $\mathrm{n}=5$ ) increase in self-appreciation related to their body was so pronounced they eventually withdrew from or did not choose IVF treatment due to respect for their body and fear for their health.

"In the end, we preferred my health to undergoing another IVF treatment. It was not always this way ... We longed for a baby so much and didn't think about my health... That doesn't mean my health wasn't important ... but we didn't take it into account... But after all those health problems we came to the agreement that a baby is not that important when this effort puts us at risk ... Health is more important than a baby ... We agreed that we didn't mind adopting a child." (V38100)

\section{Reassessment of social relationships}

"I couldn't understand for a long time why I'm so drawn to various minorities ... but I can just see it... this feeling of being an outcast." (K53100)

The majority of the women (20/24) told us that their experience with infertility made them perceive and judge other people differently and that they found and appreciated other qualities in relationships more than before. Their statements were divided into three related subthemes: 1) intensified empathy; 2) weeding out friendships; 3) new relationships.

Most women stated that due to childlessness, they felt "singled out" (K53100), "lower quality," (T35070), "on the edge" (M4208A), "inferior" (D3903A), etc. Because of this, they reported having increased empathy for other women experiencing infertility. They also stated that they had more empathy for people who felt like an outcast due to circumstances unrelated to infertility. 
"It's very positive for me that I have more empathy for people who needn't be childless but are not part of mainstream society, they are on the edge. I wouldn't think about it without this experience." (M4208A)

Some women $(9 \mathrm{w})$ told us about their general deepened empathy for people.

"I try to be more perceptive when I am with people. I know that people sometimes react in strange ways because they are trying to conceal something... and that all of us have some pain, either apparent or hidden, it depends. No one can see I am not able to have a baby. It makes an impression I have everything - a perfect husband, a good life... But it does not mean there isn 't any suffering. We only show our masks and it's good to get closer to people and see the truth." (F30070)

Some women (16w) told us that their group of friends changed, while some of them (7w) described the change in their family relationships - mainly with their mothers. The women pulled away from acquaintances who had children, as well as friends who were insensitive towards their infertility. The women described a process of 'weeding out' by not maintaining these relationships. They sorted out their friends by their ability to feel sympathy for the situation of people with infertility.

“...Even our friends were weeded out. Some of them proved to be real friends, some of them ceased to be our friends anymore and some of them became closer friends than before, because some people see it in other ways." (V38100)

Most women (11w) stated that they lost some friends and acquaintances, but they also found new ones because of their experience with infertility. These new friends had similar experiences in some cases - they also could not have children $(4 \mathrm{w})$, they met during adoption courses ( $3 \mathrm{w})$, or they just suddenly appeared in their lives $(4 \mathrm{w})$. The participants' statements prove that their choices of friends depended on the empathy and sensitivity to the participants' suffering.

"Sure, we lost some friends, but we found the new ones who knew our situation and although they didn't have the same problem, they treated us differently in some ways." (T35070) 
"My relationships started to change markedly. Only one friend remained, but I made other, nicer and deeper relationships. "(I44032)

\section{Philosophy of life}

“...We know nothing, in fact. There is hope. But that's all.” (S36050)

All 24 participants mentioned that their suffering made them try to find significance in the experience of infertility. They searched for meaning in their current and future lives as a way to recover from the struggles they faced. Three subthemes were included: 1) seeking hope; 2) seeking answers for the meaning of life and suffering; 3) spirituality - attention paid to the spiritual interpretation of existence.

Some women spoke about the difficulty of recovering after their failed efforts and their decreased ability to believe in a better future. Two women said the idea of the future without a child was connected to hopelessness and darkness, and two women stated that such an idea felt like an (inner) death for them. They tried to find a way to maintain 'hope'(K39040, G33050), hold onto 'belief' (S36050), and find a way to see 'something (good) in the future.' (M4208A). Some of these women $(8 \mathrm{w})$ described that the ability or opportunity to learn from suffering and open oneself up to other things in life could be the way out.

“... I have learned to trust that in situations when something interrupts my plans, I can carry on. Whenever I am overwhelmed by self-pity, I tell myself, that my desire for a child is natural, but there are other good things. It is important not to become closed off, because that is not life." (S36050)

Some women $(4 \mathrm{w})$ spoke about seeking alternative life paths. Other women $(9 \mathrm{w})$ considered the idea of an "open future" and "seeking hope" by pursuing adoption or foster care.

"I felt relief when we applied for adoption for the first time... Suddenly I felt that the time I have is not an endless, changeless time any more ... that there is hope again. "(K39040) 
For 16 women, the infertility experience made them think about the meaning of their life. They asked themselves if a childless life had any meaning or if there is another life mission for them. They believed there must be some deeper sense of everything $(6 \mathrm{w})$, although some were still not able to find it $(3 \mathrm{w})$. Some of them described a "substitute," meaning that they had already found (6w) and that this meaning sprang forth from deep adversity and hopelessness.

“... I asked myself, what was I supposed to do? What is my mission? After all, every woman, in a family, should give birth to a baby... isn't it her task? Well, I found the answer, but it was very, very painful and, grievous. Once I even stood along train tracks, wanting to jump in front of a train. So hard it was. And then I told myself, I had to reconcile. I can give myself to a career, maybe that's my mission here, this way I could carry on. I also thought about leaving for developing countries." (J47102).

"...I try to tell myself that there are other life missions besides raising children ... maybe helping other people." (A32060)

Some women $(14 \mathrm{w})$ started to seek an explanation for their situation in various spiritual interpretations of life and the universe - in Christianity (6w), Eastern doctrines (2w), and esotericism (3w). For some (5w), the infertility experience made them seek the spiritual meaning of existence. On the other hand, four women reported that their infertility interrupted their existing faith and brought unexpected doubt. They noted if they wanted to preserve their faith, they had to change their current attitudes.

"I needed to find out the reason. This started my seeking and investigating the meaning of life. Why are we here? Why me in this situation? What am I supposed to do? How should I cope with it? Seeking the meaning ... in suffering. I looked for the answers in esotericism. I tried to find meaning in everything possible." (K53100)

"I have always thought that God has some plan for me, but I had a problem with accepting His offer. Maybe I just didn't want to accept it. However, there came a moment when I told myself: „, Your Will will be done, but give me enough strength 
to survive so as not to go mad, because I had already been at rock bottom with depression..." (P41052)

\section{Discussion}

The results of this qualitative study support previous quantitative findings that shows PTG is connected to infertility (Kong et al., 2018; Paul et al., 2010; Yu et al., 2014) and offers a more detailed look into how PTG is experienced. Women in the study connected the stressful and lifechanging aspects of infertility to the resulting positive changes they experienced. As such, this study discovered five main aspects of PTG reported by Czech women even if they remained childless, had a child through adoption, or eventually had their own biological child after repeated unsuccessful infertility treatments.

The most commonly discussed theme was strengthening partnerships - a finding that has been stated in other research studies (Batool \& de Visser, 2016, Smidt et al., 2005; Daniluk, 2001, Lee et al., 2009, Peterson et al., 2011). The majority of women identified previously unknown but positive qualities in their partners during the years spent trying to conceive (e.g., a commitment to stay with them even without a child, an ability to accept an adopted child, and a willingness to support them and endure their difficult emotional challenges). Women also reported that communication with their partner improved overall as a result of difficult discussions around childlessness. However, strengthening partnerships did not always result in lasting relationships; two women stated that their infertility was one of the main reasons they had separated from their partner.

The lack of control women experience during fertility treatment is often a source of significant psychological distress (Clarke, Martin-Matthews \& Matthews, 2006, Cunningham, 2014). While participants in this study discussed losing control in many aspects of their lives, 
several women reported gaining a new appreciation for personal humility, which included more profound respect for life and accepting that life often unfolds differently than our plans. These findings provide hope that growth can result from this destabilizing experience. In other studies, humility was reported by couples who expressed a sense of acceptance while reflecting on their experience with infertility treatment (Daniluk, 2001). In our study, personal humility was also experienced as an increased awareness that personal failures are not always the result of poor effort. These findings are supported by results from a study of Chinese women (Lee et al., 2009) who expressed similar sentiments of humility following unsuccessful IVF treatments.

Previous studies have found that the experience of infertility significantly alters social relationships (Johanson \& Berg, 2005, Batool \& de Visser, 2016). While this effect is commonly linked to increased personal distress, the results from the current study shed novel light on this phenomenon. Rather than viewing altered social relationships solely in negative terms of avoidance and loss, this study showed that part of this realignment was intentional - a choice to limit unwanted, undesirable relationships. In addition, many women reported finding new friends who were either in similar situations or were understanding of their infertility experience, a finding supported by recent studies (Batool \& de Visser, 2016). Many women also described acquiring empathy for marginalized and excluded groups, as well as an ability to be perceptive and sensitive to other people's suffering. This increased compassion for others has been found in several studies about PTG development in those who have experienced other traumatic events (Slezáčková, 2009, Calhoun \& Tedeschi, 1999).

The stress of infertility challenges and threatens one's identity and is often linked to heightened psychological distress (Alamin et al., 2020, Clarke, Martin-Matthews \& Matthews, 2006). However, from a PTG perspective, this study found that redefining one's identity also 
contributed to increased self-appreciation. Although redefining one's identity was challenging, participants were able to understand that their personal value was not based merely on motherhood. They also praised themselves for discovering that they were emotionally stronger than they previously thought (Berger et al., 2013, Paul et al., 2010, Daniluk, 2001). This awareness of one's personal strength is one of the fundamental changes within PTG (Calhoun Tedeschi, 1999). Furthermore, all participants in the study began to incorporate health-promoting behaviors into their lives by having more respect for their body, feeling increased responsibility for their own health, and making healthier life choices - a theme also found in PTG studies of cancer patients and those who have experienced trauma through a direct threat to their health or life (Slezáčková, 2009, Sears et al. 2003).

All participants reported that the experience of infertility resulted in significant changes in their life philosophy, an outcome supported by other research examining positive changes after a traumatic experience (Lee et al., 2009, Calhoun \&Tedeschi, 1999). In the current study, the women spoke about the necessity of seeking hope in times of hopelessness and meaning in times of suffering. Previous research has shown that hope is the most prominent and unremitting theme for all couples with infertility after their treatment failed. In this context, hope enabled couples to continue trying for a child despite failed treatments (Boden, 2007). In the current study, participants also mentioned the necessity of seeking a substitute goal (or meaning) in life. Some discovered this purpose through adoption, while others discovered meaning through openness to alternative life missions. Previous research defined this construct as meaning-based coping and found that it was related to decreased distress in women after the completion of unsuccessful fertility treatment (Peterson et al., 2009). Some of the women we interviewed reported that this change in their philosophy extended to their spiritual practices, either strengthening their existing 
faith or providing a path to new spiritual learning. This heightened need to address religious and spiritual issues is one of the main changes of PTG, as reported by Tedeschi and Calhoun (1999), and arises similarly in other traumatic experiences (Zeligman, 2019). The Czech Republic is one of the least religious countries globally (Hošek, 2012), so many women stated that they began to deal with spirituality for the first time.

The study's findings are limited by the qualitative study design, sampling procedure, and number of participants. PTG is a subjective phenomenon and is limited by retrospective selfreporting and reflection. It is also quite possible that the same type of research could bring different results when carried out in other European countries or different cultures (Alamin et al. 2020, Greil et al., 2010). In the Czech Republic, societal pressure on motherhood is probably not as strong as in developing countries; however, having a child remains one of the most important values (Slepičková, 2014). High-quality infertility treatment is relatively available; three basic attempts at IVF for women under 39 are covered by health insurance. Also, in the Czech Republic, the ethical restrictions on assisted reproduction are less strict than in many European countries, partially due to the weaker influence of religion on Czech culture. Thus, the experience of PTG in our study may be shaped by culture, religion, and society in the Czech Republic. Because of this, we cannot generalize our results to all women with long-term infertility.

\section{Implications of the findings for counseling and future research}

This study provides preliminary evidence that a long-standing experience of infertility in women can lead to elements of PTG. Because this topic has been relatively unexplored in infertility literature, findings from this study can benefit patients with infertility and offer directions for future research. Specifically, patients currently experiencing infertility can find hope in the 
possibility of PTG. Findings can also help medical and mental health providers facilitate the process of PTG in patients dealing with infertility. Future research that builds on the findings from this study is needed to add to our understanding of the relationship between the infertility experience and PTG. Longitudinal interviews could be used to identify changes in a woman's evaluation of her infertility experience over time.

Infertility can be a challenging life stressor and a heavy burden for both women and couples. However, the results of this qualitative study provide hope that growth can emerge from the suffering connected to infertility. Participants' stories shed light on the challenges of infertility and the positive changes that may arise from traumatic experiences. Participants specifically experienced PTG through strengthened partnerships, deepened humility, increased selfappreciation, reassessed social relationships, and discovering new meaning and purpose in life.

\section{Funding}

This work was supported by Ministry of Health, Czech Republic - conceptual development of research organization, Motol University Hospital, Prague,Czech Republic 00064203 


\section{References}

Alamin, S., Allahyari, T., Ghorbani, B., Sadeghitabar, A. \& Karami M. T. (2020). Failure in identity building as the main challenge of infertility: A qualitative study. Journal of Reproduction \& Infertility, 21(1), 49-58.

Batool, S. S., \& Visser, R. O. (2016). Experiences of infertility in British and Pakistani women: A cross-cultural qualitative analysis. Health Care for Women International, 37, 180-196. https://doi.org/10.1080/07399332.2014.980890

Berger, R. Paul, M. S. \& Henshaw , L. A. (2013). Women's Experience of Infertility: A Multisystemic Perspective. Journal of International Women's studies, 14(1), 53-68.

Boden, J. (2007). When IVF treatment fails. Human Fertility, 10, 93-98. https://doi.org/10.1080/14647270601142614

Boivin, J., Bunting, L., Collins, J. A., \& Nygren, K.G. (2007). International estimates of infertility prevalence and treatment-seeking: Potential need and demand for infertility medical care. Human Reproduction, 22(6), 1506-1512. https://doi.org/10.1093/humrep/dem046

Braun, V., \& Clarke, V. (2012). Thematic analysis. In H. Cooper, P. M. Camic, D. L. Long, A. T. Panter, D. Rindskopf, \& K. J. Sher (Eds.), APA handbook of research methods in psychology, Vol. 2. Research designs: Quantitative, qualitative, neuropsychological, and biological (pp. 57-71). American Psychological Association.

Calhoun, L. G., \& Tedeschi, R. G. (1999). Facilitating posttraumatic growth. A clinician's guide. (1999). Lawrence Erlbaum Associates.

Calhoun, L. G., \& Tedeschi, R. G. (2006). Handbook of Posttraumatic growth: Research and practice. Lawrence Erlbaum Associates.

Clarke, L. H., Martin-Matthews, A. N., \& Matthews, R. (2006). The continuity and discontinuity of the embodied self in infertility. Canadian Review of Sociology,43(1), 95-113. https://doi.org/10.1111/j.1755-618X.2006.tb00856.x

Cunningham, N. (2014). Lost in transition : Women experiencing infertility. Human Fertility, 17(3), 154-158. https://doi.org/10.3109/14647273.2014.930517

Daniluk, J. C. (2001). "If we had it to do over again...": Couples' reflections on their experiences of infertility treatments. The Family Journal, 9(2), 122-133. https://doi.org/10.1177/1066480701092006 
Daniluk, J. C., \& Tench, E. (2007). Long term adjustment of infertile couples following unsuccessful medical intervention. Journal of Counseling and Development, 85(1), 89-100. https://doi.org/10.1002/j.1556-6678.2007.tb00448.x

Fahrenberg, J., Myrtek, M., Schumacher, J., \& Brahler, E. (2001). Dotazník životní spokojenosti. Překlad a předmluva: Rodný, T., Rodná, K. Praha: Testcentrum.

Greil, A., Slauson-Blevins, K., \& McQuillan, J. (2010). The experience of infertility: A review of recent literature. Sociology of Health \& Illness, 32(1), 140-162. https://doi.org/10.1111/j.1467-9566.2009.01213.x

Hanna, E., \& Gough, B. (2015). Experiencing male infertility: A review of the qualitative research literature. Sage Open 5(4), 1-9. https://doi.org/10.1177/2158244015610319

Hošek, P. (2012). A bohové se vracejí. Proměny náboženství v postmoderní době. Jihlava: Mlýn. Johanson, M. \& Berg, M. (2005) Women's experience of childlessness: 2 years after the end of in vitro fertilization treatment. Scandinavian Journal of Caring Sciences, 19(1), 58-63. https://doi.org/10.1111/j.1471-6712.2005.00319.x

Konečná, H. (2009). Na cestě za ditětem. Dvě malá křílla. Praha: Galén.

Kong, L., Fang, M., Ma, T., Li, G., Yang, F., Meng, Q., Li, Y., \& Li, P. (2018). Positive affect mediates the relationships between resilience, social support and posttraumatic growth of women with infertility. Psychology, Health \& Medicine, 23(6), 707-717. https://doi.org/10.1080/13548506.2018.1447679

Lee, G. L., Choi, W. H. H., Chan, C. H.Y., Chan, A.L.W. \& Ng, E. H. Y. (2009). Life after unsuccessful IVF treatment in an assisted reproduction unit: a qualitative analysis of gains through loss among Chinese persons in Hong Kong. Human Reproduction, 24(8), 19201929. https://doi.org/10.1093/humrep/dep091

Lincoln, Y. S., \& Guba, E. G. (1985). Naturalistic inquiry. Sage Publications.

Luk, B. H., \& Loke A.Y. (2015). The impact of infertility on the psychological well-being, marital relationships, sexual relationships, and quality of life of couples: A systematic review. Journal of Sex \& Marital Therapy,41(6), 610-25. https://doi.org/10.1080/0092623X.2014.958789

Miovský, M. (2006). Kvalitativní př́stup a metody v psychologickém výzkumu. Praha: Grada Publishing. a.s.

Nowell, L. S., Norris, J. M., White, D. E., Moules, N. J. (2017). Thematic analysis: Striving to 
meet the trustworthiness criteria. International Journal of Qualitative Methods, 16, 1-13. https://doi.org/10.1177/1609406917733847

Paul, M. S., Berger, R., Berlow, N., Ronvner-Ferguson, H., Figlerski, L., Gardner, S., \& Malave, A. F. (2010). Posttraumatic growth and social support in individuals with infertility. Human Reproduction, 25(1), 133-141. https://doi.org/10.1093/humrep/dep367

Peterson, B. D., Pirritano, M., Christensen, U., Boivin, J., Block, J., \& Schmidt, L. (2009). The longitudinal impact of partner coping in couples following 5 years of unsuccessful fertility treatments. Human Reproduction, 24, 1656-1664. https://doi.org/10.1093/humrep/dep061

Peterson, B. D., Pirritano, M., Block, J., \& Schmidt, L. (2011). Marital benefit and coping strategies in men and women undergoing unsuccessful fertility treatments over a 5-year period. Fertility \& Sterility, 95, 1759-1763.

Ratislavová, K. \& Kašová, L. (2009). Psychosomatický doprovod při léčbě sterility v centrech asistované reprodukce. Zdravotnické štúdie, 2(2), 73-77.

Schmidt L., Holstein, B., Christensen, U., \& Boivin, J. (2005). Does infertility cause marital benefit? An epidemiological study of 2250 women and men in fertility treatment. Patient Education Counseling, 59, 244-251. https://doi.org/10.1016/j.pec.2005.07.015

Sears, S. R., Stanton, A. L., \& Danoff-Burg, S. (2003). The yellow brick road and the emerald city: Benefit finding, positive reappraisal coping and posttraumatic growth in women with early-stage breast cancer. Health Psychology, 22(5), 487-97. https://doi.org/10.1037/02786133.22.5.487

Slepičková L. (2006). Nedobrovolná bezdětnost jako sociologické téma. Sociologický časopis/ Czech Sociological Review 42, 937-951.https://doi.org/10.13060/00380288.2006.42.5.05

Slepičková L. (2009). Neplodnost jeho a neplodnost její: Genderové aspekty asistované reprodukce. Sociologický časopis/ Czech Sociological Review 45, 177-203. https://doi.org/10.13060/00380288.2009.45.1.08

Slepičková L. (2014). Diagnóza neplodnost. Sociologický pohled na zkušenost nedobrovolné bezdètnosti. Brno: Sociologické nakladatelství.

Slezáčková A. (2009). Posttraumatický rozvoj osobnosti v kontextu pozitivní psychologie. Sborník praci filozofické fakulty Brněnské Univerzity 13, 45-59.

Sternke, E. A., \& Abrahamson, K. (2015). Perceptions of women with infertility on stigma and disability. Sexuality and Disability, 33(1), 3-17. https://doi.org/10.1007/s11195-014-9348-6. 
Tedeshi, R. G., \& Calhoun, L. G. (2004). Posttraumatic growth: Conceptual foundations and empirical evidence. Psychological Inquiry, 15(1), 1-18.

Yu, Y., Peng, L., Chen, L., Long, L., He, W., Li, M., \& Wang, T. (2014). Resilience and social support promote posttraumatic growth of women with infertility: The mediating role of positive coping. Psychiatry Research, 215, 401-405.

https://doi.org/10.1016/j.psychres.2013.10.032

Zeligman, M., McElroy-Heltzel, S. E., Davis, E. B., Dispenza, F., Davis, D. E., \& DeBlaere, C. (2019). Posttraumatic growth and trauma in flood survivors: Contribution of attitudes toward god. Journal of Mental Health Counseling, 4(2), 127-143.

https://doi.org/10.17744/mehc.41.2.03 
Table 1

Demographic data of women $(\mathrm{N}=\mathbf{2 4})$

\begin{tabular}{llll}
\hline & N & M (\%) & SD \\
\hline Age & & 38,8 & 5.4 \\
$30-36$ & 9 & $(37 \%)$ & \\
$37-43$ & 10 & $(42 \%)$ & \\
$44<$ & 5 & $(21 \%)$ & \\
Years trying to conceive & & 6.2 & 2.6 \\
$8-10$ & 9 & $(38 \%)$ & \\
$5-7$ & 8 & $(33 \%)$ & \\
$<4$ & 7 & $(29 \%)$ & \\
Education & & & \\
University degree & 22 & $(92 \%)$ & \\
Secondary school & 2 & $(8 \%)$ & \\
Current family status & & & \\
With no child & 11 & $(46 \%)$ & \\
With biological child & 8 & $(33 \%)$ & \\
$\quad$ With adopted child & 5 & $(21 \%)$ & \\
Diagnostic status & & & \\
Female factor & 7 & $(29 \%)$ & \\
Male factor & 3 & $(13 \%)$ & \\
Couple factor & 5 & $(21 \%)$ & \\
Unexplained factor & 9 & $(37 \%)$ & \\
\hline
\end{tabular}


Table 2. The frequency of reported Post-Traumatic Growth (PTG) by themes and sub-themes

\begin{tabular}{|c|c|c|c|c|c|c|c|c|c|c|c|c|c|c|c|}
\hline & \multicolumn{3}{|c|}{ PARTNERSHIP } & \multicolumn{3}{|c|}{ HUMILITY } & \multicolumn{3}{|c|}{$\begin{array}{c}\text { SELF- } \\
\text { APPRECIATION }\end{array}$} & \multicolumn{3}{|c|}{$\begin{array}{c}\text { SOCIAL } \\
\text { RELATIONSHIPS }\end{array}$} & \multicolumn{3}{|c|}{$\begin{array}{c}\text { PHILOSOPHY OF } \\
\text { LIFE }\end{array}$} \\
\hline & 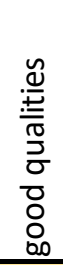 & 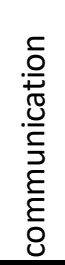 & 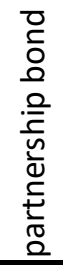 & 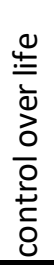 & 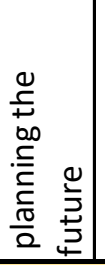 & 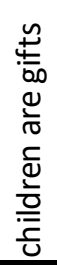 & 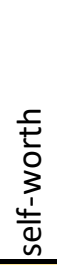 & 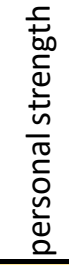 & 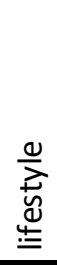 & 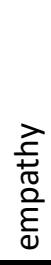 & 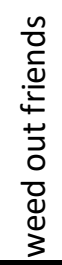 & 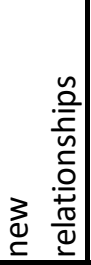 & 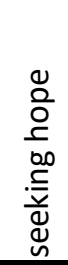 & 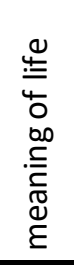 & 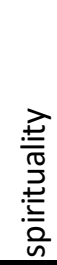 \\
\hline & \multicolumn{3}{|c|}{$n=24$} & \multicolumn{3}{|c|}{$n=21$} & \multicolumn{3}{|c|}{$n=24$} & \multicolumn{3}{|c|}{$n=20$} & \multicolumn{3}{|c|}{$n=24$} \\
\hline \multicolumn{16}{|l|}{ No child } \\
\hline V38100 & & 1 & 1 & & & & & 1 & 1 & & 1 & & 1 & 1 & \\
\hline A32060 & & & 1 & 1 & 1 & & 1 & 1 & 1 & & 1 & 1 & 1 & 1 & 1 \\
\hline S36050 & & 1 & & & 1 & & 1 & 1 & & & & 1 & 1 & 1 & 1 \\
\hline T35070 & & & 1 & 1 & & & 1 & & 1 & 1 & 1 & 1 & & I & \\
\hline J3908T & 1 & & 1 & & & & & & 1 & & 1 & & & I & \\
\hline K53100 & 1 & & & . & & 1 & 1 & , & & 1 & 1 & & 1 & 1 & 1 \\
\hline T3510T & & & 1 & 1 & & & 1 & 1 & & & & & & 1 & 1 \\
\hline $\mathrm{J} 41100$ & & 1 & & 1 & & & 1 & 1 & 1 & 1 & 1 & 1 & 1 & & 1 \\
\hline K39040 & 1 & 1 & 1 & 1 & & & 1 & 1 & 1 & & 1 & & 1 & 1 & 1 \\
\hline F30070 & 1 & & 1 & 1 & & 1 & & 1 & 1 & 1 & 1 & & & 1 & 1 \\
\hline G33050 & & 1 & & & & 1 & & 1 & 1 & & & 1 & 1 & 1 & \\
\hline sum & 4 & 5 & 7 & 6 & 2 & 3 & 7 & 8 & 8 & 4 & 8 & 5 & 7 & 10 & 7 \\
\hline \multicolumn{16}{|l|}{$\begin{array}{l}\text { Biological } \\
\text { child }\end{array}$} \\
\hline$J 352,52$ & & 1 & 1 & & 1 & & & & 1 & & & & 1 & & \\
\hline 144032 & 1 & & & & & 1 & & & 1 & 1 & 1 & 1 & & 1 & \\
\hline L41081 & 1 & & & & & & & 1 & 1 & & 1 & 1 & & 1 & 1 \\
\hline M34042 & 1 & & & & 1 & & 1 & 1 & 1 & & & & & & 1 \\
\hline M38031 & 1 & & 1 & 1 & & & & 1 & & & 1 & 1 & 1 & & \\
\hline $\mathrm{J} 47102$ & & & 1 & & & 1 & 1 & 1 & & & 1 & & 1 & 1 & \\
\hline P41052 & 1 & 1 & 1 & & 1 & 1 & & & 1 & & & & 1 & 1 & 1 \\
\hline E322,5T & 1 & & 1 & & 1 & & & & 1 & 1 & 1 & & & & 1 \\
\hline sum & 6 & 2 & 5 & 1 & 4 & 3 & 2 & 4 & 6 & 2 & 5 & 3 & 4 & 4 & 4 \\
\hline \multicolumn{16}{|l|}{$\begin{array}{l}\text { Adopted } \\
\text { child }\end{array}$} \\
\hline M4208A & 1 & 1 & 1 & & 1 & 1 & & & 1 & 1 & & & 1 & & 1 \\
\hline D3903A & & 1 & & & 1 & & & 1 & 1 & 1 & 1 & 1 & & & 1 \\
\hline M4407A & 1 & 1 & & & 1 & & 1 & & & & & 1 & & 1 & 1 \\
\hline O3905A & & & 1 & 1 & & & & & 1 & 1 & 1 & 1 & 1 & & \\
\hline D4608A & 1 & 1 & 1 & & 1 & & & 1 & & & 1 & & 1 & 1 & \\
\hline sum & 3 & 4 & 3 & 1 & 4 & 1 & 1 & 2 & 3 & 3 & 3 & 3 & 3 & 2 & 3 \\
\hline TOTAL & 13 & 11 & 15 & 8 & 10 & 7 & 10 & 14 & 17 & 9 & 16 & 11 & 14 & 16 & 14 \\
\hline
\end{tabular}




\section{Schema I}

Five aspects of posttraumatic growth in women with a long-standing experience of involuntary childlessness

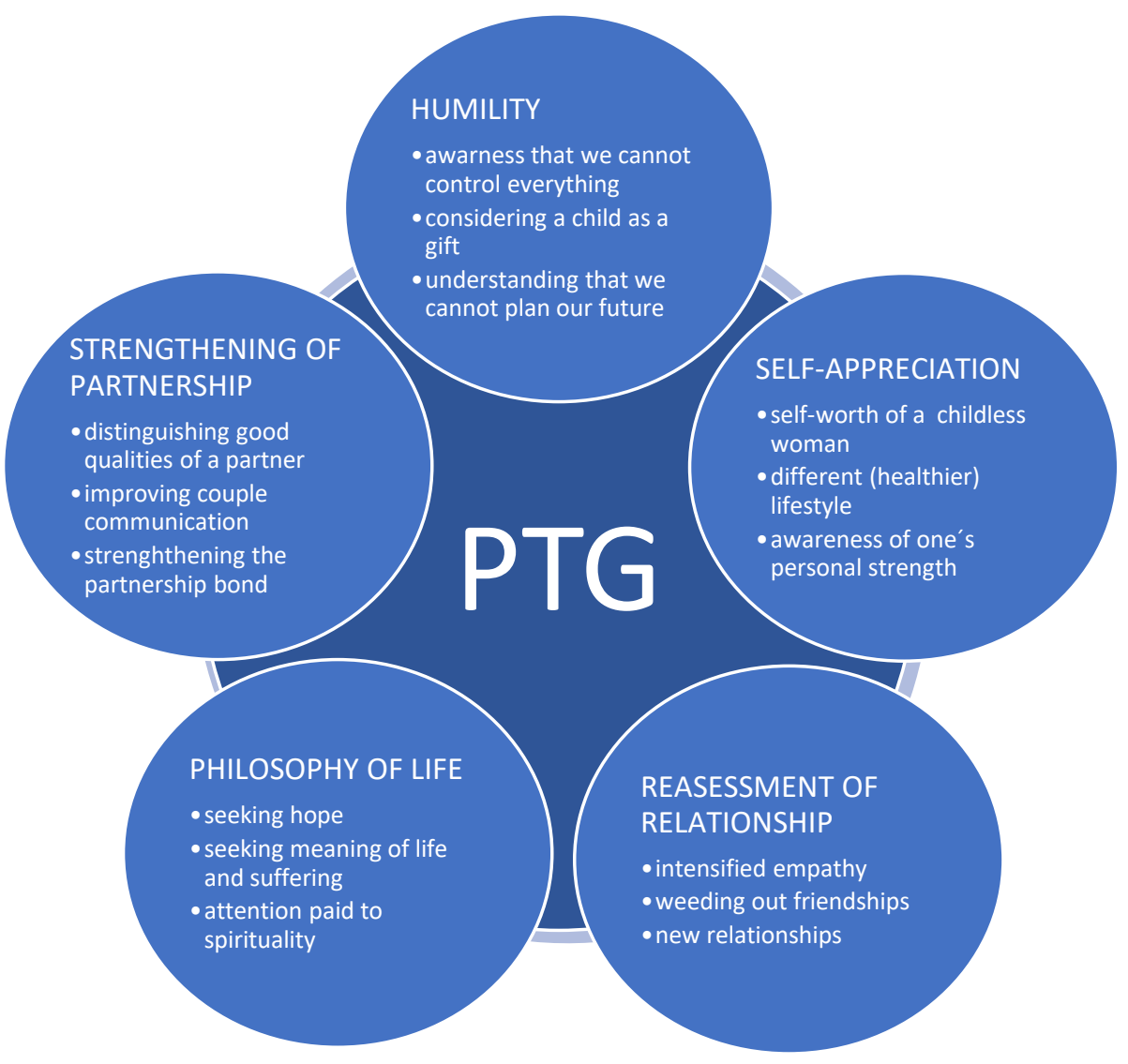

